\title{
INTERNAL SERVICE QUALITY AND EXTERNAL SERVICE QUALITY USING TWO VERSIONS OF SERVQUAL SCALE: AN EMPIRICAL EVIDENCE FROM FIVE MALLS IN THE CAPITAL CITY OF SAUDI ARABIA
}

\author{
Bader M. ALMOHAIMMEED
}

\author{
Qassim University, Buraydah, Saudi Arabia \\ E-mail:bmam@qu.edu.sa
}

Received 10 November 2018; accepted 02 January 2019

\begin{abstract}
Much of service quality research has been carried out on external service quality, i.e., services delivered by organizations to their own customers. The aim of this study was to investigate the influence of internal service quality (ISQ) on external service quality (ESQ), under the existence of variables such as learning organization (LO), employee job satisfaction (ES) and employee loyalty (EL). The study posited three conceptual models from which the best one was adopted based on the results of goodness of fitness indices. The sample comprised 500 employees working in five malls in the capital city of Saudi Arabia and 500 customers visited the same places during data collection process. The required data was collected using a questionnaire administered to the participated employees and customers. Out of the distributed questionnaires, 367 questionnaires were returned from employees and 384 questionnaires from customers. Returned questionnaires were analyzed using IMBSPSS.23 and AMOS.22. The results revealed a non-significant influence of LO on ISQ. From employees' viewpoints, ISQ was regarded as a main driver of their satisfaction and but not of their loyalty. Nevertheless, the findings showed that both employee job satisfaction (EM_SAT) and employee loyalty (EM_LOY) have significant influences on ESQ as measured on the basis of customers' perspectives. Lastly, ISQ has a significant impact on ESQ.
\end{abstract}

Keywords: external service quality, internal service quality, employee loyalty, employee job satisfaction, employee-based SERVQUAL, customer-based SERVQUAL.

JEL Classification: L81, M3, M19, M31.

\section{Introduction}

The first impression of service quality (SQ) designates the service quality delivered to customers by a service organization (Iqbal et al. 2018). It goes without asking who is the customer, because the intended customer here is the ultimate one who receives the service. In fact, an organization has two major types of customers: external customers or clients as well as internal customers or employees. Therefore, service quality can be arranged into two classes, which were external service quality (ESQ) and internal service quality (ISQ). In the same context, Latif et al. (2016) categorized service quality into two forms: ISQ and ESQ. They defined ISQ as quality of services provided to coworkers by employees from different organizational units in the same organization, and determined ESQ as quality of service delivered by the organization to its own customers. Dauda et al. (2013) named two approaches used in the literature to assess service quality: outside-in-approach and inside-out-approach. According to them, the focus of the first one is on the customers outside the organization, while the focus of the second one is on customers inside (employees) the organization. For Ahmed et al. (2011), service quality was categorized into two types; ISQ, which represents employee's attitudes towards their work, coworkers and the organization itself, and perceived service quality (PSQ), which refers to customer's perceptions of the service he or she received. For the present study ESQ is identical with PSQ.

Since Marshall et al. (1998) to Latif et al. (2016), it was observed that much of service quality research was conducted

\footnotetext{
Copyright $\odot 2019$ The Authors. Published by VGTU Press.

This is an Open Access article distributed under the terms of the Creative Commons Attribution License (http://creativecommons.org/licenses/by/4.0/), which permits unrestricted use, distribution, and reproduction in any medium, provided the original author and source are credited..
} 
to explore external service quality in comparison to research carried out to evaluate internal service quality. Vassileva and Balloni (2014) argued that the definition of service quality is mostly centered to customers, i.e., external customers. Many researchers underlined the significance of studying not only the quality of services delivered to external customer but also the quality of services exchanged among collogues within the organization (Omid et al. 2014). In the same line, numerous studies were conducted to investigate internal service quality. Abu El-Samen and Alshurideh (2012) used a sample consisted of employees working at a pharmaceutical organization in Saudi Arabia to investigate the effect of internal marketing on ISQ. Dauda et al. (2013) examined the impact of ISQ on employee job satisfaction of a library staff in Nigeria. Fitwi and Abdissa (2016) investigated the impact of ISQ on employee job satisfaction in commercial bank of Ethiopia. Jumadi (2014) explored the impact of internal marketing and ISQ on employee job satisfaction in tourism sector in Indonesia. Wang (2012) verified the influence of ISQ on employee job satisfaction in Taiwan hotels. Al-Ababneh et al. (2018) indicated that the ISQ influence on an employee's job satisfaction in five-star hotels in Jordan. Susanti et al. (2015) examined the influence of ISQ on patient behavioral intentions in Indonesia. Singh (2016) studied the impact of ISQ on employee job performance in public sector in Malaysia. Khan et al. (2011) modeled a link between ISQ in human resources management and employee retention in private and public sectors in Pakistan.

This study seeks to make a modest contribution by aggregating the effort make in previous studies by investigating the influence of internal service quality on external service quality in Saudi settings. Moreover, the study applied the most cited measurement of service quality, SERVQUAL, to evaluate service quality. Hence, two versions of SERVQUAL were elaborated based on related works to measure external service quality and internal service quality. In order to explore roles played by other variables in the relationship between ISQ and ESQ, three variables were added to enrich the model tested in this study; learning organization, employee job satisfaction and employee loyalty.

\section{Theoretical background}

\subsection{ISQ definition}

User-based approach is one approach used by authors to define quality. According to Yarimoglu (2014), the main idea behind that approach is to compare quality level of a service consumed with customers' satisfaction. Due to the intrinsic differences between goods and services, the author added that the measurement of service quality, known as perceived service quality, presents the actual level of a service provided by a service provider as perceived by the customer. Fadil et al. (2016) defined ISQ as employees' satisfaction that results from their good perceptions' about service provided by internal providers of services within the organization. In their internal service quality model, Frost and Kumar (2000, as cited in Dauda et al. 2013 and Yarimoglu 2014) conceptualized ISQ as a difference between expected and perceived serviced services an employee from front-line staff feels in consequence of service delivered by their co-workers or support staff. Recurrence to Hallowell's (1996, as cited in Susanti et al. 2015) definition of ISQ, it was explained that ISQ is a state of satisfaction realized by an employee as an internal customer by reason of his or her perception of a service delivered by another employee as an internal service provider. For Heskett et al. (1994, as cited in Sankaran et al. 2014), ISQ is concerned with equipping employees with skills that enable them to serve internal customers. Marshall et al. (1998) defined ISQ as a "tow-way exchange process" in which employees as providers of services offer their co-workers those service to meet their needs and make them satisfied.

\subsection{ISQ dimensions}

Several models of service quality were reported in the literature. Yarimoglu (2014) brought out a privileged review of service quality models (SQM) included Grönroos (1984) SQM, Parasuraman et al. (1985) GAP SQM, HaywoodFarmer (1988) SQM, SERVQUAL model developed by Parasuraman et al. (1988), SERVPERF model developed by Cronin and Taylor (1992), Retail Service Quality Scale developed by Dabholkar et al. (1996) and internal service quality model (INTSERVQUAL) developed by Frost and Kumar (2000) in addition to Brady and Cronin's (2001) SQM. In order explore quality gaps in an organization, Kamakoty and Sohani (2013) suggested that SRVQUAL can be used to achieve this goal. One set of previous studies used amended items of the SERVQUAL scale that developed by Parasuraman et al. (1988) with five dimensions; assurance, reliability, responsiveness, empathy, and tangibles. The modified version of SERVQUAL was known as Internal Service Quality Battery (ISQB). It consists of the same dimensions of SERVQUAL with items adapted to reflect services provided by co-workers within the organization (Fadil et al., 2016). Kang et al. (2002) confirmed using SERVQUAL in measuring ISQ. Gunawardane (2009), Jumadi (2014) and Fitwi and Abdissa (2016) are examples of studies that used the same dimensions of SERVQUAL with employee-oriented items. Abu El-Samen and Alshurideh (2012) utilized a measurement of ISQ consisted of 22 items to measure responsiveness, reliability, tangibles, empathy and assurance. Another set of studies utilized different dimensions as shown in Table 1. Wang (2012), for example, used four items related to workplace, employees and teamwork. Ahmed et al. (2011) adopted five dimensions regarded workplace, job and employees. Concurrently, Khan et al. (2011) 
Table 1. ISQ dimensions

\begin{tabular}{|c|c|}
\hline ISQ dimensions & References \\
\hline $\begin{array}{l}\text { Delivering value, respectful treatment, } \\
\text { conscientiousness, order processing, } \\
\text { vendor management and problem } \\
\text { solving. }\end{array}$ & Marshall et al. (1998) \\
\hline $\begin{array}{l}\text { Tangibles, reliability, assurance, res- } \\
\text { ponsiveness, and empathy }\end{array}$ & $\begin{array}{l}\text { Ramseook-Munhurrun } \\
\text { et al. (2010), Abu El- } \\
\text { Samen and Alshurideh } \\
\text { (2012), Jumadi (2014), } \\
\text { Noor et al. (2014), Al- } \\
\text { Tit (2015), Fadil et al. } \\
\text { (2016), Singh (2016), } \\
\text { and Latif et al. (2016) }\end{array}$ \\
\hline $\begin{array}{l}\text { Workplace equipment/design, deve- } \\
\text { lopment and promotions, employee } \\
\text { training, job definition, employee } \\
\text { compensation and rewards, employee } \\
\text { selection and teamwork }\end{array}$ & $\begin{array}{l}\text { Khan et al. (2011), } \\
\text { Ahmed et al. (2011) and } \\
\text { Wang (2012) }\end{array}$ \\
\hline $\begin{array}{l}\text { Credibility, reliability, accessibility/ } \\
\text { tangibility, competence, preparedness }\end{array}$ & Dhurup (2012) \\
\hline $\begin{array}{l}\text { Rewards, Academic freedom, Pro- } \\
\text { fessional development support, } \\
\text { Teamwork, Vision of top management, } \\
\text { Work resources and Communication }\end{array}$ & $\begin{array}{l}\text { Joshi and Chadha } \\
(2016)\end{array}$ \\
\hline
\end{tabular}

applied five practices of human resources management to assess ISQ: employee selection, training and development, compensation and rewards in addition to work design and job definition. In general, much of the research related to external service quality used SERVQUAL dimensions to evaluate this variable. Following the majority of the previous studies, this study used SERVQUAL dimensions to measure ISQ (Abu El-Samen and Alshurideh 2012, Noor et al. 2014, Jumadi 2014, Fadil et al. 2016, Fitwi and Abdissa 2016, Latif et al. 2016).

\subsection{ESQ definition}

External service quality has been related to customers' perceptions in comparison with services expected or experienced (Randheer et al. 2011). Ramseook-Munhurrun et al. (2010) defined external service quality as a difference, identified based on customers judgment, between the quality levels of services delivered to customers and their perceptions about that quality of the service in comparison with their own expectations. Loke et al. (2011) calculated external service quality by subtracting customers' perceptions of the service from his or her expectations about that quality of the service. In fact, most of external service definitions are in accordance with Parasuraman et al (1988) definition of quality applied to the scale developed by them to measure service quality, in which service quality was described as incompatibility between customer's perceptions and expectations of the actual service they experienced.

\subsection{ESQ dimensions}

The common SERVQUAL scale developed by Parasuraman et al. (1988) has been used in many studies to measure service quality. Some studies used the same dimensions of the scale (tangibles, reliability, assurance, responsiveness, and empathy), while other studies added other dimensions or modified the same dimensions to be fit for different circumstances (Itumalla et al. 2014). For example, Randheer et al. (2011) studied external service quality using SURVQUAL dimensions; empathy, reliability, responsiveness, assurance, and tangibles, and added a sixth dimension which was "culture". The sixth dimension in SERVQUAL scale used by Sadek et al. (2010) was "compliance". Similar to many studies, the same items of SERVQUAL used to measure service quality from customers' perspectives were adopted by this study (see Table 2).

Table 2. ESQ dimensions

\begin{tabular}{|c|l|}
\hline \multicolumn{1}{|c|}{ ESQ dimensions } & \multicolumn{1}{c|}{ References } \\
\hline $\begin{array}{l}\text { Tangibles, reliability, } \\
\text { assurance, empathy, } \\
\text { and responsiveness }\end{array}$ & $\begin{array}{l}\text { Kang et al. (2002), De Man et al. (2002), } \\
\text { Palihawadana and Barnes (2004), } \\
\text { Laroche et al. (2004), Sharma and } \\
\text { Mehta (2004), Chow and Luk (2005), } \\
\text { Bhat (2004), Kattara et al. (2008), Liu } \\
\text { and Yen (2010), Marković and Raspor } \\
\text { (2010), Loke et al. (2011), Hirmukhe } \\
\text { (2012), Kim and Han (2013), Sankaran } \\
\text { et al. (2014) }\end{array}$ \\
\hline $\begin{array}{l}\text { Reliability, assurance, } \\
\text { empathy, responsive- } \\
\text { ness, and culture }\end{array}$ & Randheer et al. (2011) \\
\hline $\begin{array}{l}\text { Tangibles, reliability, } \\
\text { assurance, empathy, } \\
\text { and responsiveness } \\
\text { and compliance }\end{array}$ & Sadek et al. (2010) \\
\hline
\end{tabular}

\subsection{Learning organization}

Leaning organization has been described as an organizational vision that enables organizations to cope with different environmental changes through the reinforcement of learning activities (Tsai 2014). Arma et al. (2016) defined learning organization as a workplace where employee can enhance their capacities through continuous learning. Skuncikiene et al. (2009) connected the definition of learning organization to numerous aspects that stamp learning organizations such as the importance of learning as a vital part of the organizational culture and a mean of change adaptation, knowledge acquisition and sharing, in addition to continuous learning and employee development. In relation to learning organization dimensions, Pantouvakis and Mpogiatzidis (2013) used empowerment and continuous learning to measure learning organization. Tsai (2014) identified continuous learning and training 
as a core feature of learning organization. Through these tools, employees were enabled to serve customers with high-quality services. Leufvén et al. (2015) adapted learning organization model that developed by Marsick and Watkins (2003). That model comprised of the following dimensions: team learning and collaboration, dialogue and inquiry, systems connections, continuous learning, empowerment, embedded systems, and strategic leadership. The same model was also adopted by Arma et al. (2016). For the current study, learning organization was conceptualized as an organization provides its employees with continuous learning employee and development opportunities.

\subsection{Employee job satisfaction}

According to Khuong and Tien (2013), the most common definition of employee job satisfaction is the one that developed by Locke (1976) in which the author defined this concept as an emotional state that result from the appraisal of job experience. Wang (2012) indicated that this definition is the one cited in the academic papers. Pantouvakis (2011) considered employee job satisfaction as a function of tangible and intangible aspects of internal service quality. Dauda et al. (2013) indicated that the common way of measuring employee job satisfaction is by asking them to rate their perceptions about their jobs in relation to their salaries, responsibilities, opportunities of advancements, the job itself, and their colleagues. In a study conducted by Javadi et al. (2013), employee job satisfaction was measured using three variables: feelings about the job compensation, organizational climate and compensation. Piriyathanalai and Muenjohn (2012) measured employee satisfaction in terms of compensation, job advancements, job responsibilities, work climate, supervision style, and individual recognition. In their study on the impact of ISQ on employee job satisfaction, Fitwi and Abdissa (2016) evaluated job satisfaction based on employees' satisfaction on work, people, promotions, and supervision. Kim and Han (2013) employed six dimensions to measure employee job satisfaction; workplace environment, performance appraisal, compensation, job content, relationships with colleagues and supervisors. Wang (2012) measured employee job satisfaction using employees' feelings towards their jobs, advancements, pay, and relationships with supervisors and co-workers.

\subsection{Employee loyalty}

Loyalty in general refers to individual's association to an object such as another person, a group, an organization, a responsibility, etc. an employee loyalty to an organization is classified under a larger umbrella known in the literature as organizational commitment (Iqbal et al. 2015). Hence, employee loyalty has been defined as employee commitment to stay with a particular organization and to do his or her best to maintain the success of that organization (Pandey and Khare 2012, Iqbal et al. 2015). Preko and Adjetey (2013) identified leadership, human relationships, creativity, personal development and employee job satisfaction as key determinants of employee loyalty. Chaturvedi (2010) recommended based on the results of her study to utilize the indicators of emotional commitment to enhance employee commitment. According to her, empowerment, mutual commitment, employee recognition, upright communication, and opportunities for employee development were key motives of employee loyalty. Susanti (2015) considered employee job satisfaction as a major antecedent of employee loyalty that results in improved external service quality. Similarly, Itam and Singh (2017) found a significant association between job satisfaction and employee loyalty.

\section{Hypotheses development}

\subsection{LO and ISQ}

Learning as a process is essential for all organizations, by which employees can enhance their skills (Dawoood et al. 2015). Hays and Hill (2000) confirmed that the organizational effort directed to transform an organization to a learning organization in order to enhance service quality make no sense in the absence of employee motivation and vision. They defined employee motivation in terms of their desire to deliver high quality services, and conceptualized vision as employee awareness of the importance of service quality for the organization. Abdar and Beheshtifar (2016) studied the relationship between organizational learning culture using dimensions like strategic leadership, continuous learning, team learning, and empowerment and internal service quality using tangibles, responsibility, guarantee, trust, empathy, and found a significant association between learning culture dimensions and internal service quality. That is an increase in learning culture dimensions results in an increase in internal service quality. Consequently, it was suggested that:

Hypothesis 1. LO has a significant influence on ISQ.

\subsection{ISQ, ES and EL}

Research on ISQ and employee-related outcomes revealed multifarious results. Those findings revealed positive influences of ISQ on job satisfaction (Wang 2012, Pantouvakis and Mpogiatzidis 2013, Susanti 2015, Fitwi and Abdissa 2016), employee empowerment, job satisfaction and continuous learning (Pantouvakis and Mpogiatzidis 2013), job performance (Singh 2016), employee job satisfaction (Osahon and Kingsley 2016), employee satisfaction, commitment and loyalty (Ahmed et al. 2011) and organizational performance (Al-Tit 2017, Naser et al. 2013). Dhurup (2012) examined the relationship between ISQ and employee satisfaction using five dimensions of ISQ; credibility, 
reliability, accessibly, competence and preparedness and found that ISQ explained a good percent of variability in employee satisfaction. In their study on ISQ, Sankaran et al. (2014) argued that ES is a main result of ISQ. Jumadi (2014) pointed out significant impact of internal marketing and ISQ on employee job satisfaction. In contrast, results of some previous studies, e.g. Dauda et al. (2013), pointed out that ISQ has no significant influence job satisfaction. Ramseook-Munhurrun et al. (2010) studies the influence of internal service quality measured by SERVQUAL dimensions on employee satisfaction and loyalty and found that all dimensions of SERVQUAL except tangibles have negative significant influences on employee satisfaction and loyalty. Based on the above results, the following hypotheses were proposed:

Hypothesis 2. ISQ has a significant influence on employee satisfaction.

Hypothesis 3. ISQ has a significant influence on employee loyalty.

\subsection{ES, EL and ESQ}

Ahmed et al. (2011) asserted that the satisfaction of internal customers is a major inducement of external customer satisfaction. Parasuraman et al. (1985, as cited in Kumar et al. 2008) emphasized the importance of employee satisfaction as well as service quality for customer satisfaction. Piriyathanalai and Muenjohn (2012) considered employee satisfaction as a critical component of the improvement of external service quality. According to them, supervision style was the most important factor in relation service quality, followed by job advancements, working climate, job responsibilities, recognition, and finally, salary. Susanti et al. (2015) indicated that employee (nurse) job satisfaction has a significant impact on external service quality, which in turn affects patient satisfaction. The results of Kim and Han (2013) clarified a partial significant impact of employee job satisfaction on external service quality. Particularly, their results demonstrated that three dimensions of job satisfaction, which were employee compensation, performance appraisal, and relationships with colleagues, influenced external service quality. Yee et al. (2008), in a study conducted in shopping centers in Hong Kong, found a positive impact of employee job satisfaction on external service quality. From Prabbakar's (2016) viewpoint, levels of employee satisfaction and loyalty in service quality domain could be understood from workplace environment characteristics, that is, good states of relationships among colleagues, transparency in work and incentives policies, job security, employee empowerment and growth opportunities enable the employees to contribute to provide high quality services. Based on these results, two hypotheses were suggested:

Hypothesis 4. ES has a significant influence on ESQ. Hypothesis 5. EL has a significant influence on ESQ.

\subsection{ISQ and ESQ}

Many previous studies found a positive as well as significant influence of ISQ on ESQ. In their study on public and private universities in Indonesia, Susanti et al. (2015) highlighted that ISQ was significantly and directly influenced ESQ. For Berry et al. (2002), ISQ has been considered as interactions result in solutions adopted to solve customers' problems. In a study conducted in banking sector in Pakistan by Ahmed et al. (2011), the significant relationship between ISQ perceived by employees and ESQ perceived by customers was supported. Based on these findings, the following hypothesis was suggested:

Hypothesis 6. ISQ has a significant influence on ESQ.

\section{Methodology}

\subsection{Sample}

Keeping in mind that this study contains two measures of service quality; internal service quality (quality of employees' service) and external service quality (quality of customers' service), the sample of the study comprised both employees and customers due to the fact that employees are best like to report their perceptions related to the quality of internal services they received and customers are favored to express their perspectives concerned the quality of external service they consumed. Hence, the sample included 500 employees working in five malls in the capital city of Saudi Arabia and 500 customers visited the same malls during data collection process. The required data was collected using two questionnaires distributed to employees and customers simultaneously. Employees' questionnaire involved items used to measure learning organization, internal service quality, employee job satisfaction, and employee loyalty. On the other hand, customers' questionnaire embraced was itemized to evaluate internal service quality. A total of 367 (response rate $=73.4 \%$ ) and 384 (response rate $=76.8 \%$ ) questionnaires were returned from employees and customers respectively.

\subsection{The conceptual models}

\subsubsection{Proposed models}

Kumar et al. (2008) suggested using more than one conceptual model when a researcher employs the structural modeling equation (SEM). Yee at al. (2008) confirmed that the optimal application of SEM is to select the best model from alternative models. This study tests three conceptual models. The first model, shown in Figure 1, posited five relationships between learning organization (LO) and employee job satisfaction (EM_SAT), ISQ and employee loyalty (EM_LOY), EM_SAT and ESQ, EM_LOY and ESQ as well as ISQ and ESQ. In a learning organization, employees are continuously learned to acquire knowledge and 
skills on how to execute their job tasks, and empowered to do those tasks by their own way in harmony with the intended organizational objectives. These characteristics were hypothesized to affect their job satisfaction, which in turn influences customer's perceptions of service quality. ISQ as measured by internal SERVQUAL was assumed to affect ESQ as measured by external SERVQUAL, and to affect employee loyalty. A loyal employee, one who is appreciated, empowered and on his or her way to be promoted, was postulated to influence the quality of service delivered to customers.

The second alternative conceptual model, exhibited in Figure 2, presumed five relationship between the same variables; LO and ISQ, EM_SAT and ESQ, ISQ and EM_ LOY, EM_LOY and ESQ, and ISQ and ESQ. This model was developed based on raising another idea with reference to characteristics an employee possesses as a member of learning organization. His or her knowledge, skills and motivation was proposed to influence the quality of internal service exchanged within the organization.

In the third alternative conceptual model assessed in this study, as depicted in Figure 3, the same relationships in the second alternative model were hypothesized, i.e., relationships between LO and ISQ, EM_SAT and ESQ, EM_LOY and ESQ, ISQ and EM_LOY, ISQ and ESQ in addition to a new relationship between ISQ and EM_SAT. It was acknowledged for argument that a workplace environment in which an employee realizes high levels of advanced and appealing tangibility, reliable, trustworthy, kind, attached, knowledgeable as well as skilled colleagues, quick service provision, and accurate communication and information make him or her more satisfied.

\subsubsection{Models' goodness of fit}

Eight fitness indices were used to evaluate the conceptual models, as demonstrated in Table 3, which were Chi-square ratio to degrees of freedom ( $\chi 2 / \mathrm{df})$, Root Mean Square Residual (PMR), comparative fit index (CFI), adjusted goodness-of-fit index (AGFI), Root Mean Square Error of Approximation (RMSEA), goodness-of-fit index (GFI), parsimony goodness-of-fit index (PGFI), and The TuckerLewis Index (TLI) (Kumar et al. 2008, Yee et al. 2008, Sharif 2009, Liu and Yen 2010, Khan et al. 2011, Karatepe 2012, Al-Tit 2016, Latif et al. 2016, Bello et al. 2017). Table 3 shows a summary of goodness of fit for the three conceptual

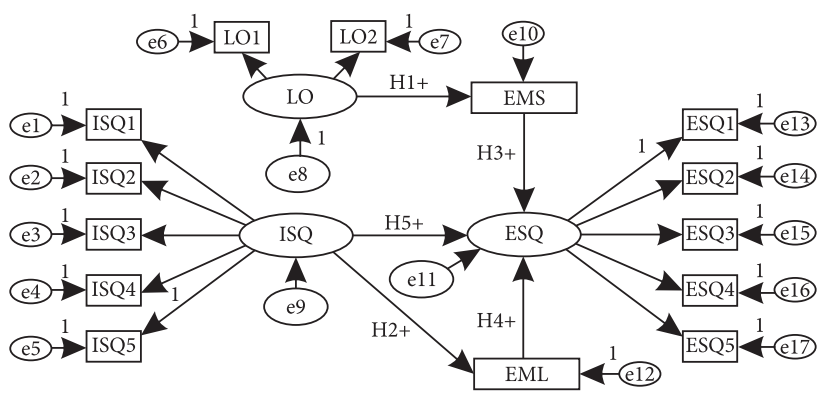

Figure 1. Conceptual model No. 1

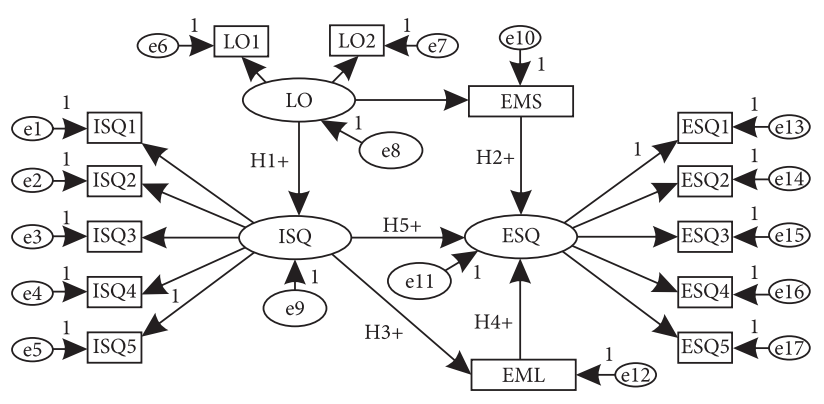

Figure 2. Conceptual model No. 2

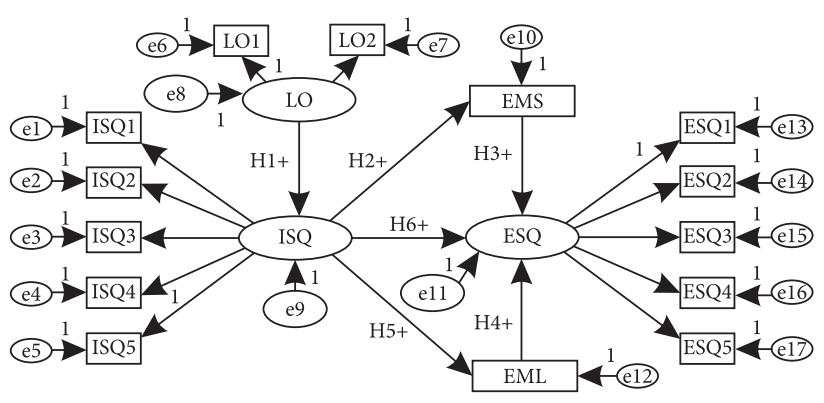

Figure 3. Conceptual model No. 3

models evaluated in this study. It was concluded that the third model is the best one based on the results of fitness indices $(\chi 2 / \mathrm{df}=1.12, \mathrm{P}=0.0214, \mathrm{PMR}=0.007, \mathrm{CFI}=$ $0.984, \mathrm{GFI}=0.972, \mathrm{AGFI}=0.956, \mathrm{PGFI}=0.601, \mathrm{RMSEA}$ $=0.00, \mathrm{TLI}=0.99)$. Based on these results the conceptual model no. 3 revealed itself as the best model in terms of goodness of fit in comparison with other models. That is, model 3 appeared to be the favorable model and was used in the analysis of the structural model.

Table 3. The summary of model's goodness of fit

\begin{tabular}{|c|c|c|c|c|c|c|c|c|c|c|c|}
\hline $\begin{array}{c}\text { Indices } \\
\text { Model }\end{array}$ & $\chi^{2}$ & $\mathrm{df}$ & Sig. & $\begin{array}{c}\chi^{2} / \mathrm{df} \\
<3\end{array}$ & $\begin{array}{c}\text { PMR } \\
<0.10\end{array}$ & $\begin{array}{c}\text { CFI } \\
>0.90\end{array}$ & $\begin{array}{c}\text { GFI } \\
>0.90\end{array}$ & $\begin{array}{c}\text { AGFI } \\
>0.90\end{array}$ & $\begin{array}{c}\text { PGFI } \\
>0.50\end{array}$ & $\begin{array}{c}\text { RMSEA } \\
<0.08\end{array}$ & $\begin{array}{c}\text { TLI } \\
>0.90\end{array}$ \\
\hline 1 & 114.22 & 76 & 0.039 & 1.50 & 0.014 & 0.960 & 0.901 & 0.934 & 0.536 & 0.01 & 0.966 \\
\hline 2 & 117.12 & 77 & 0.045 & 1.52 & 0.110 & 0.982 & 0.947 & 0.931 & 0.571 & 0.00 & 0.978 \\
\hline 3 & 109.51 & 74 & 0.064 & 1.48 & 0.007 & 0.984 & 0.972 & 0.956 & 0.601 & 0.00 & 0.99 \\
\hline
\end{tabular}




\subsection{Measures}

Leaning organization was measured using continuous learning and employee development (Pantouvakis and Mpogiatzidis 2013, Arma et al. 2016). Employee job satisfaction was measured using opportunities of advancements, employee compensation, relationships with employees and supervisors (Kim and Han 2013, Dauda et al. 2013, Fitwi and Abdissa 2016). Employee loyalty was measured using individual recognition, employee empowerment, personal development (Chaturvedi 2010). SERVQUAL scale was used to measure both internal service quality and external service quality. It consists of tangibles, reliability, responsiveness, assurance and empathy. For the purpose of this study, two versions of the scale were utilized: SERVQUAL version 1 , and 2 as shown in Tables 4 and 5. The first version was used to measure external service quality, while the second version was used to measure internal service quality. Zeithmal et al. (1990, as cited in Latif et al. 2016) indicated that SERVQUAL (external customer scale) can be adapted to measure internal service quality. Many studies used versions 1 of SERVQUAL to measure external service quality (Sharma and Mehta 2004, Palihawadana and Barnes 2004, Liu and Yen 2010). On the other hand, several researchers to measure ISQ (Kang et al. 2002, Gunawardane 2009, Abu El-Samen and Alshurideh 2012, Jumadi 2014, Noor et al. 2014, Fitwi and Abdissa 2016, Fadil et al. 2016, Latif et al. 2016) used the modified version also.

\subsection{Results of the structural model}

Model 3 that was appointed as the best model among those investigated in this study was used to carry out further analysis. According to Sandada and Matibiri (2016), a model that showed a satisfactory level of goodness of fit is ready to be used in extracting the structural equations. Prior to test the hypotheses assumed in this study, validity and reliability were evaluated. Standard loadings of items, Cronbach's alpha, the average variance extracted (AVE), discriminant

Table 4. Dimensions and items used to measure ISQ and ESQ

\begin{tabular}{|l|l|l|}
\hline \multicolumn{1}{|c|}{ Variables } & \multicolumn{1}{|c|}{ Measures } & \multicolumn{1}{c|}{ References } \\
\hline $\begin{array}{l}\text { Leaning } \\
\text { organization }\end{array}$ & $\begin{array}{l}\text { Continuous learning } \\
\text { and employee develo- } \\
\text { pment }\end{array}$ & $\begin{array}{l}\text { Pantouvakis and } \\
\text { Mpogiatzidis (2013), } \\
\text { Arma et al. (2016) }\end{array}$ \\
\hline $\begin{array}{l}\text { Employee } \\
\text { satisfaction }\end{array}$ & $\begin{array}{l}\text { Opportunities of } \\
\text { advancements, emplo- } \\
\text { yee compensation, and } \\
\text { relationships with em- } \\
\text { ployees and supervisors }\end{array}$ & $\begin{array}{l}\text { Kim and Han (2013), } \\
\text { Dauda et al. (2013), } \\
\text { Fitwi and Abdissa } \\
\text { (2016) }\end{array}$ \\
\hline $\begin{array}{l}\text { Employee } \\
\text { loyalty }\end{array}$ & $\begin{array}{l}\text { Individual recognition, } \\
\text { employee empower- } \\
\text { ment, and personal } \\
\text { development }\end{array}$ & Chaturvedi (2010) \\
\hline
\end{tabular}

validity in addition to composite reliability were used to achieve that objective. It was concluded based on the results shown in Table 6 that the scales used in this study are valid and reliable since all values met the recommended thresholds (Kumar et al. 2008, Yee at al. 2008, Sharif 2009, Liu and Yen 2010, Karatepe 2012, Latif et al. 2016).

Table 5. Dimensions and items used to measure ISQ and ESQ

\begin{tabular}{|c|c|c|c|c|}
\hline \multicolumn{2}{|c|}{$\begin{array}{c}\text { ESQ } \\
\text { Employees from } \\
\text { customer's perspective }\end{array}$} & \multirow{2}{*}{$\begin{array}{c}\text { SQ } \\
\begin{array}{c}\text { Dimen- } \\
\text { sions }\end{array} \\
\text { Tangibles }\end{array}$} & \multicolumn{2}{|c|}{$\begin{array}{c}\text { ISQ } \\
\text { Coworkers from } \\
\text { employee's perspective }\end{array}$} \\
\hline ISQ1-1 & $\begin{array}{l}\text { Use advanced } \\
\text { equipment }\end{array}$ & & ESQ1-1 & $\begin{array}{l}\text { Use advanced } \\
\text { equipment }\end{array}$ \\
\hline ISQ1-2 & $\begin{array}{l}\text { Have a neat } \\
\text { appearance }\end{array}$ & & ESQ1-2 & $\begin{array}{l}\text { Have a } \\
\text { comfortable } \\
\text { working } \\
\text { climate }\end{array}$ \\
\hline ISQ1-3 & $\begin{array}{l}\text { Use appealing } \\
\text { materials }\end{array}$ & & ESQ1-3 & $\begin{array}{l}\text { Use appea- } \\
\text { ling materials }\end{array}$ \\
\hline ISQ2-1 & $\begin{array}{l}\text { Provide service } \\
\text { as promised }\end{array}$ & $\begin{array}{l}\text { Relia- } \\
\text { bility }\end{array}$ & ESQ2-1 & $\begin{array}{l}\text { Provide } \\
\text { service as } \\
\text { promised }\end{array}$ \\
\hline ISQ2-2 & $\begin{array}{l}\text { Furnish correct } \\
\text { information }\end{array}$ & & ESQ2-2 & $\begin{array}{l}\text { Furnish cor- } \\
\text { rect informa- } \\
\text { tion }\end{array}$ \\
\hline ISQ2-3 & $\begin{array}{l}\text { Deliver right } \\
\text { services }\end{array}$ & & ESQ2-3 & $\begin{array}{l}\text { Deliver right } \\
\text { services }\end{array}$ \\
\hline ISQ3-1 & $\begin{array}{l}\text { Willing to help } \\
\text { customers }\end{array}$ & $\begin{array}{l}\text { Respon- } \\
\text { siveness }\end{array}$ & ESQ3-1 & $\begin{array}{l}\text { Willing to } \\
\text { help their } \\
\text { colleagues }\end{array}$ \\
\hline ISQ3-2 & $\begin{array}{l}\text { Respond } \\
\text { promptly to } \\
\text { requests }\end{array}$ & & ESQ3-2 & $\begin{array}{l}\text { Respond } \\
\text { promptly to } \\
\text { requests }\end{array}$ \\
\hline ISQ3-3 & $\begin{array}{l}\text { Have accurate } \\
\text { communi- } \\
\text { cations }\end{array}$ & & ESQ3-3 & $\begin{array}{l}\text { Have accura- } \\
\text { te communi- } \\
\text { cations }\end{array}$ \\
\hline ISQ4-1 & Trustworthy & $\begin{array}{l}\text { Assu- } \\
\text { rance }\end{array}$ & ESQ4-1 & Trustworthy \\
\hline ISQ4-2 & Kind and polite & & ESQ4-2 & $\begin{array}{l}\text { Kind and } \\
\text { polite }\end{array}$ \\
\hline ISQ4-3 & $\begin{array}{l}\text { Knowledgeable } \\
\text { and skilled }\end{array}$ & & ESQ4-3 & $\begin{array}{l}\text { Knowled- } \\
\text { geable and } \\
\text { skilled }\end{array}$ \\
\hline ISQ5-1 & $\begin{array}{l}\text { Customers' } \\
\text { interests at } \\
\text { heart }\end{array}$ & Empathy & ESQ5-1 & $\begin{array}{l}\text { Colleagues' } \\
\text { interests at } \\
\text { heart }\end{array}$ \\
\hline ISQ5-2 & $\begin{array}{l}\text { Concerned } \\
\text { about custo- } \\
\text { mers }\end{array}$ & & ESQ5-2 & $\begin{array}{l}\text { Concerned } \\
\text { about collea- } \\
\text { gues }\end{array}$ \\
\hline ISQ5-3 & $\begin{array}{l}\text { Understand } \\
\text { customers' } \\
\text { needs }\end{array}$ & & ESQ5-3 & $\begin{array}{l}\text { Understand } \\
\text { colleagues' } \\
\text { needs }\end{array}$ \\
\hline
\end{tabular}


On the other hand, the results shown in Table 7 and Figure 4 indicated that three hypotheses were rejected: learning organization has no significant influence on internal service quality $(\mathrm{SC}=0.16, \mathrm{P}>0.05)$, employee loyalty has no significant influence on external service quality $(\mathrm{SC}=0.11, \mathrm{P}>$ 0.05 , and internal service quality has no significant influence on employee loyalty ( $\mathrm{SC}=0.23, \mathrm{P}>0.05$ ). Furthermore, three hypotheses were approved: internal service quality has a significant impact on employee job satisfaction ( $\mathrm{SC}=$ $0.48, \mathrm{P}<0.05)$, employee job satisfaction has a significant influence on external service quality $(\mathrm{SC}=0.63, \mathrm{P}<0.05)$, and internal service quality has a significant influence on external service quality $(S C=0.55, \mathrm{P}<0.05)$.

Table 6. Evaluation of validity and reliability

\begin{tabular}{|c|c|c|c|c|c|c|}
\hline $\begin{array}{c}\text { Cons- } \\
\text { tructs }\end{array}$ & Items & $\begin{array}{c}\text { Standard } \\
\text { loadings }\end{array}$ & $\begin{array}{c}\text { Cron- } \\
\text { bach's } \\
\text { alpha }\end{array}$ & AVE & $\begin{array}{c}\text { Square } \\
\text { root of } \\
\text { AVE }\end{array}$ & $\begin{array}{c}\text { Com- } \\
\text { posite } \\
\text { reliability }\end{array}$ \\
\hline LO & LO1 & 0.674 & 0.741 & 0.661 & 0.813 & 0.721 \\
\hline & LO1 & 0.668 & & & & \\
\hline ISQ & ISQ1 & 0.710 & 0.779 & 0.598 & 0.773 & 0.741 \\
\hline & ISQ1 & 0.694 & & & & \\
\hline & ISQ3 & 0.770 & & & & \\
\hline & ISQ4 & 0.781 & 0.739 & 0.671 & 0.819 & 0.768 \\
\hline & ISQ5 & 0.699 & & & & \\
\hline EMS & EMS1 & 0.754 & & 0.673 & 0.820 & 0.717 \\
\hline & EMS2 & 0.801 & & & & \\
\hline & EMS3 & 0.821 & & & & \\
\hline EML & EML1 & 0.738 & 0.728 & 0.701 & 0.837 & 0.745 \\
\hline & EML2 & 0.761 & & & & \\
\hline & EML3 & 0.691 & & & & \\
\hline ESQ & ESQ1 & 0.802 & 0.758 & 0.720 & 0.848 & 0.795 \\
\hline & ESQ2 & 0741 & & & & \\
\hline & ESQ3 & 0.760 & & & & \\
\hline & ESQ4 & 0.811 & & & & \\
\hline & ESQ5 & 0.817 & & & & \\
\hline
\end{tabular}

Table 7. Results of the structural model

\begin{tabular}{|c|c|c|c|c|c|}
\hline \multicolumn{3}{|c|}{ Hypothesis } & \multirow{2}{*}{$\begin{array}{c}\begin{array}{c}\text { Standardized } \\
\text { coefficients } \\
(\mathrm{SC})\end{array} \\
0.16\end{array}$} & \multirow{2}{*}{$\begin{array}{c}\text { P value } \\
0.063\end{array}$} & \multirow{2}{*}{$\begin{array}{r}\text { Results } \\
\text { Rejected }\end{array}$} \\
\hline H1 & LO & ISQ & & & \\
\hline $\mathrm{H} 2$ & ISQ & EMS & 0.48 & $0.000^{\star}$ & Approved \\
\hline $\mathrm{H} 3$ & EMS & ESQ & 0.63 & $0.002^{*}$ & Approved \\
\hline $\mathrm{H} 4$ & EML & ESQ & 0.11 & 0.104 & Rejected \\
\hline H5 & ISQ & EML & 0.23 & 0.058 & Rejected \\
\hline H6 & ISQ & ESQ & 0.55 & $0.001^{\star}$ & Approved \\
\hline \multicolumn{6}{|c|}{${ }^{*} \mathrm{P}<0.05$} \\
\hline
\end{tabular}

\section{Discussion and conclusions}

Investigating the influence of learning organization on internal service quality, the influence of internal service quality on employee job satisfaction, employee loyalty and external service quality, the influences of employee job satisfaction and employee loyalty on external service quality were aims of this study. Utilizing two versions of SERVQUAL in measuring both internal and external service quality and specific measures adapted to measure learning organization, employee job satisfaction and employee loyalty and a sample consisted of employee as well as customers, the results, outlined in Figure 5, approved that internal service quality has a significant influence on employee job satisfaction and on external service quality. Furthermore, the results showed a significant influence of employee job satisfaction on external service quality. On the other hand, three hypotheses were rejected, there were no significant influence of learning organization on internal service quality, no significant influence of internal service quality on employee loyalty, and no significant influence of employee loyalty on external service quality. In the literature, learning organization was defined as a workplace where employee can learn through continuous learning as well as motivated by advancement opportunities (Arma et al. 2016). It was also described as an organization that empower its employees (Pantouvakis and Mpogiatzidis 2013). One of the most important advantages of learning organization, according to Tsai (2014), is to enable its employees to serve customers. Dawoood et al. (2015) characterized learning as critical success factor for all organizations. In fact, the relationship between learning organization has not gained great attention in the literature. However, in one study carried out by Abdar and Beheshtifar (2016), the significant and positive association between learning organization and internal service quality was approved. The result found in this study might be due to the measures used to evaluate learning organization, which were continuous learning and advancement opportunities. Employees probably found their advancement opportunities under their expectations. Chaturvedi (2010) stated that employees

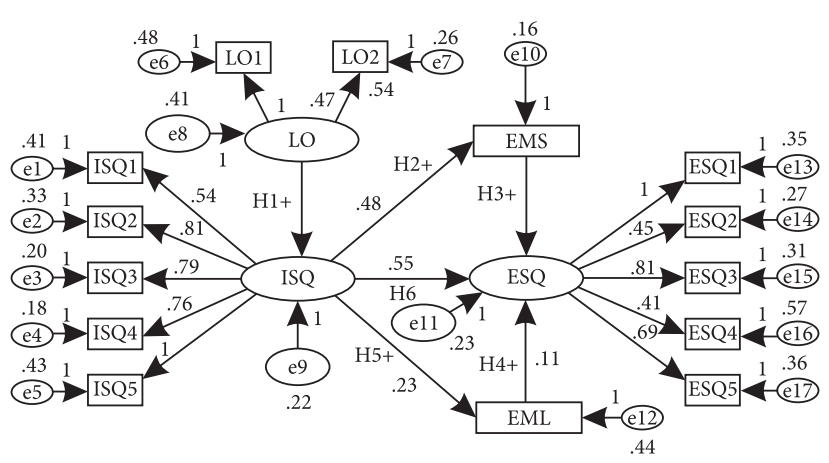

Figure 4. The structural model results 


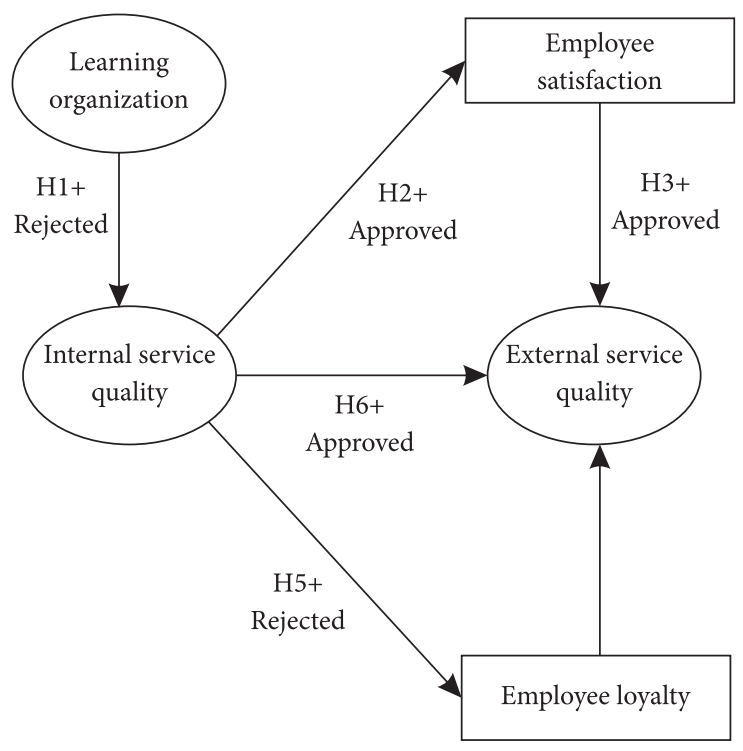

Figure 5. Summary of hypotheses testing

in different cases label these advancements as usual "jobhopping" of their career paths.

In agreement with many other studies, the results approved the significant influence of internal service quality on employee satisfaction (Ahmed et al. 2011, Wang 2012, Dhurup 2012, Pantouvakis and Mpogiatzidis 2013, Sankaran et al. 2014, Jumadi 2014, Susanti 2015, Fitwi and Abdissa 2016, Osahon and Kingsley 2016). Some previous studies rejected the hypothesis that internal service quality has a significant influence on employee job satisfaction (Dauda et al. 2013).

As can be seen in Figure 5, there is no significant influence of internal service quality on employee loyalty. An evidence of the same result was not found in the literature. Previous results confirmed that internal service quality is positively related to employee loyalty (RamseookMunhurrun et al. 2010, Osahon and Kingsley 2016). The significant influence of internal service quality on employee job satisfaction has no effect on the relationship between internal service quality and employee loyalty. According to Prabhakar (2016), employee satisfaction was not in all cases result in employee loyalty. Internal service quality was characterized as state results from interaction, support and communication levels dominant among employees (Latif et al. 2016). These characteristics do not mean employee recognition, empowerment or personal development opportunities as main indicators of loyalty, as measured in this study, that the management must practice and support.

Analyzing the current data, a significant influence of employee job satisfaction on external service quality was supported as revealed in numerous studies (Kumar et al. 2008, Yee et al. 2008, Ahmed et al. 2011, Piriyathanalai and Muenjohn 2012, Susanti et al. 2015). In spite of the positive association between job satisfaction and employee loyalty, as outlined in Itam and Singh (2017), employee loyalty has no significant impact on external service quality. Pandey and Khare (2012) and Iqbal et al. (2015) defined employee loyalty in terms of employee commitment to stay with the organization and to do his or her best to raise organizational success. Loyalty was measured in this study based on individual recognition, employee empowerment, and personal development and posited to have an influence on external service quality in case of loyal employees. A justification of the non-significant influence of employee loyalty might be attributed to loyalty conceptualization from employees' perspectives. Another definition might found in employees' minds. In her study, Chaturvedi (2010) suggested emotional and mutual commitment as drivers of employee loyalty. Finally, the result found that internal service quality has a significant influence on external service quality. Similar findings were echoed in the literature (Berry et al. 2002, Ahmed et al. 2011, Susanti et al. 2015). According to Berry et al. (2002), internal service quality produces solutions that can be applied to solve customers' problems. Based on the above results, it was concluded that internal service quality plays critical role in employee job satisfaction which in turn affects external service quality.

\section{Recommendations, limitations and future research}

Organizations should pay internal service quality more attention due to its role in employee satisfaction and external quality enhancement. This can be achieved by ensuring that co-workers use advanced service-related equipment, have a neat appearance, provide their colleagues with services as promised from the first time, communicate correct and accurate information, will to help their colleagues, trustworthy, knowledgeable and skilled, and understand their colleagues needs. Practitioners must encourage these features in order to maintain their human resource capital. Additionally, organizations are required to determine factors that reinforce their employee loyalty. This study is limited to a sample of employees and customers elected from five malls in the capital city, caution should be considered in results generalization. Further research should be carried in order to explore the impact of learning organization on internal service quality, to identify the effect of internal service quality on employee loyalty using different measures, and to investigate the impact of employee loyalty on customer satisfaction. These relationships were not approved in the current study.

\section{References}

Abdar Z, Beheshtifar M (2016) Examine the relationship between organizational learning cultures on quality of services of staff in Kerman University of Medical Sciences in 2014. Journal of Administrative Management, Education and Training (JAMET) 13 (3): 181-190. 
Abu El-Samen A, Alshurideh M (2012) The impact of internal marketing on internal service quality: A case study in a Jordanian pharmaceutical company. International Journal of Business and Management 7 (19): 84-95.

Ahmed I, Razzaque R, Ramzan M (2011) Examining the links between employee and customer variables of service profit chain: A case of Pakistani banks. Australian Journal of Basic and Applied Sciences 5 (11): 1634-1645.

Al-Ababneh et al. (2018) The impact of internal service quality on job satisfaction in the hotel industry. Research in Hospitality Management 8 (1): 55-62. https://doi.org/10.1080/22243534 .2018 .1501182

Al-Tit A (2015) The effect of service and food quality on customer satisfaction and hence customer retention. Asian Social Science 11 (23): 129-139. https://doi.org/10.5539/ass.v11n23p129

Al-Tit A (2016) The mediating role of knowledge management and the moderating part of organizational culture between HRM practices and organizational performance. International Business Research 9 (1): 43-54. https://doi.org/10.5539/ ibr.v9n1p43

Al-Tit A (2017) Factors Affecting the Organizational performance of manufacturing firms. International Journal of Engineering Business Management 9: 1-9. https://doi. org/10.1177/1847979017712628

Arma A, Hamzah D, Alam S, Ismail M (2016) Learning organization in implementation new public services at Palu Local Government, Indonesia. Journal of Research in Business and Management 3 (12): 8-19.

Bello M, Martin D, Kasim R, Abubakar M, Umar (2017) An examination of relationship between quality municipal services and citizen satisfaction in Malaysian Local Council, Batu Pahat in perspective. Path of Science 3 (5): 1-4. https://doi. org/10.22178/pos.22-2

Berry L, Carbone L, Haeckel S (2002) Managing the total customer experience. MIT Sloan Management Review 43 (3): 85-89.

Bhat M (2004) Correlates of service quality in banks: an empirical investigation. Journal of Services Research 5: 77-99.

Brady MK, Cronin JJ (2001) Some new thoughts on conceptualizing perceived service quality: A hierarchical approach. Journal of Marketing 65 (3): 34-49. https://doi.org/10.1509/ jmkg.65.3.34.18334

Chaturvedi V (2010) A study of organizational loyalty among employee in service industry: A study with reference to selected service industries in Faridabad. i-manager's Journal on Management 51 (31): 30-36.

Chow C, Luk P (2005) A strategic service quality approach using analytic hierarchy process. Managing Service Quality 15 (3): 278-289. https://doi.org/10.1108/09604520510597827

Cronin JJ, Taylor SA (1992) Measuring service quality - A reexamination and extension. Journal of Marketing 56 (3): 55-68. https://doi.org/10.2307/1252296

Dabholkar PA, Thorp DI, Rentz JO (1996) A Measure of service quality for retail stores: scale development and validation. Journal of the Academy of Marketing Science 24 (3): 3-16. https://doi.org/10.1007/BF02893933

Dauda A, Maishanu M, Mawoli M (2013) Effect of internal service quality on employee job satisfaction: Evidence from Abubakar
Gimba Library, IBB University, Lapai - Nigeria. American International Journal of Contemporary Research 3 (6): 88-96.

Dawoood S, Mammona Fahmeeda, Ahmed A (2015) Learning organization: Conceptual and theoretical overview. International Journal of Humanities Social Sciences and Education (IJHSSE) 2 (4): 93-98.

De Man S, Gemmel P, Vlerick P, Van Rijk P, Dierckx R (2002) Patients' and personnel's perceptions of service quality and patient satisfaction in nuclear medicine. European Journal of Nuclear Medicine and Molecular Imaging 29: 1109-1117. https://doi.org/10.1007/s00259-002-0869-3

Dhurup M (2012) Determinants of internal service quality and the relationship with internal customer satisfaction. African Journal of Business Management 6 (11): 4185-4195. https:// doi.org/10.5897/AJBM11.2386

Fadil H, Singh K, Joseph C (2016) The influence of organizational innovation towards internal service quality in MBKS. Procedia - Social and Behavioral Sciences 224: 317-324. https:// doi.org/10.1016/j.sbspro.2016.05.491

Fitwi T, Abdissa G (2016) The impact of internal service climate on employees' job satisfaction: With reference to commercial bank of Ethiopia, Gedeo zone. Global Journal of Management and Business Research 16 (2): 11-30.

Frost FA, Kumar M (2000) INTSERVQUAL - an internal adaptation of the GAP model in a large service organisation. Journal of Services Marketing 14 (5): 358-377. https://doi. org/10.1108/08876040010340991

Grönroos C (1984) A service Quality model and its marketing implications. European Journal of Marketing 18 (4): 36-44. https://doi.org/10.1108/EUM0000000004784

Gunawardane G (2009) Relationship between dimensions of internal service quality and the nature of the internal service encounter: A study in the healthcare industry. California Journal of Operations Management 7 (1): 21-30.

Haywood-Farmer J (1988) A conceptual model of service quality. International Journal of Operations \& Production Management 8 (6): 19-29. https://doi.org/10.1108/eb054839

Hays J, Hill A (2000) A preliminary investigation of the relationships between employee motivation/vision, service learning, and perceived service quality. Journal of Operations Management 250: 1-15.

Hirmukhe J (2012) Measuring internal customers' perception on service quality using SERVQUAL in administrative service. International Journal of Scientific and Research Publications 2 (3): $1-6$.

Iqbal A, Tufail M, Lodhi R (2015) Employee loyalty and organizational commitment in Pakistani organizations. Global Journal of Human Resource Management 3 (1): 1-11.

Iqbal S, Hassan M, Habibah U (2018) Impact of self-service technology (SST) service quality on customer loyalty and behavioral intention: The mediating role of customer satisfaction. Cogent Business \& Management 5: 1423770.

Itam U, Singh S (2017) Examining the mediation effect of employee engagement on internal brand practices and outcome variables in the organized retail sector. International Business Management 11 (3): 673-682.

Itumalla R, Acharyulu G, Shekhar B (2014) Development of HospitalQual: A service quality scale for measuring. in-patient 
services in hospital. Operations and Supply Chain Management 7 (2): 54 -63. https://doi.org/10.31387/oscm0170108

Javadi M, Rezaee M, Salehzadeh R (2013) Investigating the relationship between self-leadership strategies and job satisfaction. International Journal of Academic Research in Accounting. Finance and Management Sciences 3 (3): 284289. https://doi.org/10.6007/IJARAFMS/v3-i3/178

Joshi P, Chadha SK (2016) Measuring internal service quality in business schools. International Journal of Services and Standards 11 (4): 357-379. https://doi.org/10.1504/ IJSS.2016.082434

Jumadi (2014) Influence of internal marketing toward internal service quality and impact to internal customer satisfaction: Case study in tourism industry in Yogyakarta Special Territory of Indonesia. The International Journal of Business \& Management 2 (1): 69-73.

Kamakoty J, Sohani N (2013) Measuring service quality in supply chain: Proposed model. Asian Journal of management Research 3 (2): 313-324.

Kang G, James J, Alexandris K (2002) Measurement of internal service quality: Application of the SERVQUAL battery to internal service quality. Managing Service Quality 12 (5): 278-291. https://doi.org/10.1108/09604520210442065

Karatepe O (2012) Perceived organizational support, career satisfaction, and performance outcomes: A study of hotel employees in Cameroon. International Journal of Contemporary Hospitality Management 24 (5): 735-752. https://doi. org/10.1108/09596111211237273

Kattara H, Weheba D, El-Said O (2008) The impact of employee behavior on customers' service quality perceptions and overall satisfaction. Tourism and Hospitality Research 8: 309-323. https://doi.org/10.1057/thr.2008.35

Khan M, Kashif-Ur-Rehman, Ijaz-Ur-Rehman, Safwan N, Ahmad A (2011) Modeling link between internal service quality in human resources management and employees retention: A case of Pakistani privatized and public sector banks. African Journal of Business Management 5 (3): 949-959.

Khuong M, Tien B (2013) Factors influencing employee loyalty directly and indirectly through job satisfaction - A study of banking sector in Ho Chi Minh City. International Journal of Current Research and Academic Review 1 (4): 81-95.

Kim P, Han P (2013) Effects of job satisfaction on service quality, customer satisfaction, and customer loyalty: The case of a local state-owned enterprise. WSEAS Transactions on Business and Economics 1 (10): 49-68.

Kumar V, Smart P, Maddern H, Maull R (2008) Alternative perspectives on service quality and customer satisfaction: the role of BPM. International Journal of Service Industry Management 19 (2): 176-187. https://doi.org/10.1108/ 09564230810869720

Laroche M, Ueltschy L, Abe S, Cleveland M, Yannopoulos P (2004) Service quality perceptions and customer satisfaction: Evaluating the role of culture. Journal of International Marketing 12 (3): 58-85. https://doi.org/10.1509/jimk.12.3.58.38100

Latif K, Baloch Q, Rehman S (2016) Role of internal service quality (ISQ) in the linkage between perceived organizational support and organizational performance. City University Research Journal 6 (1): 1-22.
Leufvén M, Vitrakoti R, Bergström Ashish K, Målqvist M (2015) Dimensions of learning organizations questionnaire (DLOQ) in a low-resource health care setting in Nepal. Health Research Policy and Systems 13 (6): 1-8. https://doi. org/10.1186/1478-4505-13-6

Liu C, Yen L (2010) The effects of service quality, tourism impact, and tourist satisfaction on tourist choice of leisure farming types. African Journal of Business Management 4 (8): 15291545.

Locke EA (1976) The nature and causes of job satisfaction. Handbook of industrial and Organizational Psychology, Chicago, Rand McNally.

Loke S, Taiwo A, Salim H, Downe A (2011) Service quality and customer satisfaction in a telecommunication service provider. International Conference on Financial Management and Economics. IPEDR 11: 24-29.

Marković S, Raspor S (2010) Measuring perceived service quality using servqual: a case study of the Croatian hotel industry. Management 5 (3): 195-209.

Marsick V, Watkins K (2003) Demonstrating the value of an organization's learning culture: The dimensions of learning organizations questionnaire. Advances in Developing Human Resources 5: 132-151. https://doi.org/10.1177/1523422303005002002

Marshall G, Baker J, Finn D (1998) Exploring internal customer service quality. Journal of Business and Industrial marketing 13 (4/5): 381-392. https://doi.org/10.1108/08858629810226681

Naser B, Esmaeil Z, Masood J, Mahmood S (2013) The relationship between internal service quality and physical education faculty members' job satisfaction in dist. 10 of Islamic Azad University, Iran. European Journal of Experimental Biology 3 (2): 379-382.

Noor K, Rajiani I, Sulaiman N (2014) The applicability of internal marketing factors to boost Internal service quality. International Journal of Innovative Science, Engineering \& Technology 1 (9): 202-215.

Omid M, Ebrahim A, Bagher G (2014) Factors associated with internal service quality from the perspective of staff in Golestan' sports and youth offices. European Journal of Experimental Biology 4 (2): 347-350.

Osahon O, Kingsley O (2016) Statistical approach to the link between internal service quality and employee job satisfaction: A case study. American Journal of Applied Mathematics and Statistics 4 (6): 178-184.

Palihawadana D, Barnes B (2004) The measurement and management of service quality in dental healthcare. Health Services Management Research 17 (2): 29-36. https://doi. org/10.1258/0951484042317750

Pandey C, Khare R (2012) Impact of job satisfaction and organizational commitment on employment loyalty. International Journal of Social Science \& Interdisciplinary Research 1 (8): 26-41.

Pantouvakis A (2011) Internal service quality and job satisfaction synergies for performance improvement: Some evidence from a B2B environment. Journal of Targeting, Measurement and Analysis for Marketing 19: 11-22. https://doi.org/10.1057/ jt.2011.2

Pantouvakis A, Mpogiatzidis P (2013) The impact of internal service quality and learning organization on clinical 
leaders' job satisfaction in hospital care services. Leadership in Health Services 26 (1): 34-49. https://doi.org/10.1108/ 17511871311291714

Parasuraman A, Zeithaml V, Berry L (1988) SERVQUAL: a multiple-item scale for measuring consumer perceptions of service quality. Journal of Retailing 64 (1): 12-40.

Parasuraman A, Zeithaml VA, Berry LL (1985) A Conceptual Model of Service Quality and Its Implications for Future Research. Journal of Marketing 49 (4): 41-50. https://doi. org/10.2307/1251430

Parasuraman A, Zeithaml VA, Berry LL (1988) Servqual: A Multiple-Item Scale For Measuring Consumer Perceptions of service quality. Journal of Retailing 64 (1): 12-40.

Piriyathanalai W, Muenjohn N (2012) Is there a link? Employee satisfaction and service quality. World Journal of Management 4 (1): 82-92.

Prabhakar A (2016) Analysis of high job satisfaction relationship with employee loyalty in context to workplace environment. International Journal of Applied Research 2 (4): 640-643.

Preko A, Adjetey J (2013) A study on the concept of employee loyalty and engagement on the performance of sales executives of commercial banks in GHANA. International Journal of Business Research and Management (IJBRM) 4 (2): 51-62.

Ramseook-Munhurrun P, Naidoo P, Lukea-Bhiwajee S (2010) Measuring service quality: Perceptions of employees. Global Journal of Business Research 4 (1): 47-58.

Randheer K, AL-Motawa A, Vijay P (2011) Measuring commuters' perception on service quality using SERVQUAL in public transportation. International Journal of Marketing Studies 3 (1): 21-34. https://doi.org/10.5539/ijms.v3n1p21

Sadek D, Zainal N, Taher M, Yahya A (2010) Service quality perceptions between cooperative and Islamic Banks of Britain. American Journal of Economics and Business Administration 2 (1): 1-5. https://doi.org/10.3844/ajebasp.2010.1.5

Sandada M, Matibiri B (2016) An investigation into the impact of service quality, frequent flier programs and safety perception on satisfaction and customer loyalty in the airline industry in Southern Africa. South East European Journal of Economics and Business 11 (1): 41-53. https://doi.org/10.1515/ jeb-2016-0006

Sankaran E, Sundaram K, Kirubakaran D (2014) A study on internal customer satisfaction towards maintenance of equipments in industries. International Journal of Advanced Technology in Engineering and Science 20 (5): 352-358.
Singh K (2016) Influence of internal service quality on job performance: A case study of Royal Police Department. Procedia - Social and Behavioral Sciences 224: 28-34. https://doi. org/10.1016/j.sbspro.2016.05.396

Skuncikiene S, Balvociut R, Balciunas S (2009) Exploring characteristics of a learning organization as learning environment. Social Research 1 (15): 64-75.

Susanti C (2015) The influence of internal service quality toward patient's behavioral intention in inpatient unit at the type C General Hospitals in East Java, Indonesia. Journal of Nursing and Health Care (JNHC) 3 (1): 171-178. https://doi. org/10.5176/2345-718X_3.1.106

Susanti E, Sule E, Sutisna H (2015) The Impact of Internal and External Service Quality: A Case Study among Lecturers and Students. Mediterranean Journal of Social Sciences 6 (5): 77 83. https://doi.org/10.5901/mjss.2015.v6n5s5p77

Sharif K (2009) Relationship between intra-and interorganizational service quality perceptions: an empirical testing of modified service profit chain model within Kuwaiti telecommunications industry. Services. Marketing Quarterly 30 (3): 249-269. https://doi.org/10.1080/15332960902993502

Sharma A, Mehta V (2004) Service quality perceptions in financial services - a case study of banking services. Journal of Services Research 4 (2): 205-223.

Tsai Y (2014) Learning organizations, internal marketing, and organizational commitment in hospitals. BMC Health Services Research 14 (152): 2-8. https://doi.org/10.1186/14726963-14-152

Vassileva B, Balloni A (2014) Service quality measurement: implications for healthcare sector in Bulgaria. 11th International Conference on Information Systems and Technology Management - CONTECSI May, 28 to 30, 2014 - São Paulo, Brazil.

Wang G (2012) The influence of internal service quality on employee job satisfaction at Taiwan-listed international tourist hotels: using organizational culture as the moderator. World Transactions on Engineering and Technology Education 10 (3): 174-183.

Yarimoglu E (2014) A review on dimensions of service quality models. Journal of Marketing Management 2 (2): 79-93.

Yee R, Yeung A, Cheng T (2008) The impact of employee satisfaction on quality and profitability in high-contact service industries. Journal of Operations Management 26: 651-668. https://doi.org/10.1016/j.jom.2008.01.001 